\title{
Analysis of Individual Entrepreneurial Orientation and Self-Esteem Toward Entrepreneurial Intention (case of Business Program Students at Telkom University)
}

\author{
Kristina Sisilia $^{1}$ and Nizar Sabiq ${ }^{2}$ \\ ${ }^{1}$ Telkom University, Indonesia, e-mail: kristina@telkomuniversity.ac.id \\ ${ }^{2}$ Telkom University, Indonesia
}

\begin{abstract}
Entrepreneur must adapt and still be able to provide products or services required by their customers in a fast-changing business environment. Entrepreneurs should assess their competence and capability and students should do the same if they want to start their new business. Students business programs has a business orientation to start with and do business with intention, confidence, and knowledge at their disposal during their studies. This study aims to determine the level of student or individual entrepreneurial orientation (IEO) and their self-esteem towards entrepreneurial intention. This study examines entrepreneurial intentions in students in finding and using business opportunities by optimizing their potential. We want to test the differences in the IEO, self-esteem and entrepreneurial intentions that occur in the 2015 and 2016 program student business classes at Telkom University. We conducted pair t-test because there were differences in some subjects of entrepreneurship that could lead to differences in self-esteem and individual entrepreneurial orientation (IEO) towards their entrepreneurial intentions. The survey through questionnaire distribution shows a strong correlation between IEO and self-esteem and that the 2016 class scores higher than the 2015 class for IEO scores and self-esteem towards their entrepreneurial intentions. This study shows that dimensions such as Risk Taking, Innovation, and Pro-activity in the IEO and dimensions of performance, appearance, and social dimensions in the self-esteem variable in the 2016 class are higher than the 2015 class towards their entrepreneurial intentions.
\end{abstract}

Keywords: Individual Entrepreneurial Orientation, Self-Esteem, Entrepreneurial Intention, business students.

\section{Introduction}

Entrepreneurship and innovation discuss how we get success in business. Peter Drucker himself said there was a close relationship between entrepreneurship and innovation so there was a lot of knowledge about these two things. In fact, many academic researchers publish their research that identifies entrepreneurial companies and determines how company characteristics are related to company performance. Entrepreneurial companies consist of employees or individuals who have the character and practice of entrepreneurship so that the overall performance of the company is competitive. Entrepreneurial Orientation (EO) knows the extent of the characteristics that exist at the level of the company in entrepreneurial companies. This EO subject in academic research is related to corporate management practices.

Some researchers conducted research on students of business program which shows they study in a business program because they want to become entrepreneurs and start their own business. Many factors influence them to start a business and one of them is their entrepreneurial orientation (EO). Some of research then uses the EO as an important tool to define entrepreneurial characteristics that seek and define opportunities that exist in their external environment. EO measurement itself uses 5 components, autonomy, innovativeness, pro-activeness, risk-taking, and competitive aggressiveness (Dess et al., 1996). According to Lau, Shaffer, and Au (2007) states that "entrepreneurial companies extend entrepreneurs" therefore, it is important to understand and measure entrepreneurial orientation at the individual level that allows us to gain a deeper understanding of the business world and the factors that contribute to individual success, and vice versa, measuring the individual's contribution to the success of a company or organization. 
The role of the university is to develop their students' interest in entrepreneurship and explore the factors that influence entrepreneurial behavior. Entrepreneurship courses are also compulsory subjects for all study programs at Telkom University and even business programs have a focus on entrepreneurial concentration which provides various topics related to entrepreneurship. They direct business program graduates to start their own businesses or work for other companies by having the entrepreneurial abilities of individuals who can find opportunities and provide solutions. The EO component used in the study can measure the entrepreneurial characteristics of students from business programs to understand their intention to become entrepreneurs. Their main task is to study, and their parents still pay their school fee so that most of their current business activities are part-time activities. These reasons limit not to measure autonomy and competitive aggressiveness. This EO research choose the components of innovation, pro-activity and risk taking.

This study also examines other factors, namely self-esteem. Self-esteem is the overall positive or negative assessment of someone against him (Ferris, Lian, Brown, Pang, guard, 2010: 566). Research has shown that high self-esteem provides a buffer against various pressures that can hinder motivation or performance in the workplace where individuals with high self-confidence are more motivated to perform tasks in ways consistent with themselves (Ferris et al., 2010). Different situational results can affect our feelings about ourselves. Based on these results, this can be very important for the possibility of someone to pursue an entrepreneurial business. In this study, the factors used for variants of self-confidence are performance, appearance, and social dimensions. Previous articles that used the opportunity of the canvas analysis tool by Green (2015) measuring students' entrepreneurial behavior including the dimensions of self-confidence in students of the class $2014 \& 2015$ business class programs in Telkom University showed a high level of confidence in starting a business (Sisilia, 2017).

Another study by Vogelsang (2015) combines individual entrepreneurial orientation and self-esteem in his research entitled Individual Entrepreneurial Orientation: Student assessment, concluding that there is a strong correlation between individual entrepreneurial orientation and self-esteem. Selfesteem does not show a direct correlation with the tendency to work for themselves or start their own business. Aslam et al. (2012) conducted the same research for students in Pakistan, showing students taking part in entrepreneurship education were more interested in entrepreneurship, compared to students who did not take part in entrepreneurship education. A similar study at Telkom University shows that Entrepreneurship courses have an influence $81.9 \%$ of students are interested in becoming entrepreneurs (Hatammimi and Fauziyah, 2013: 85).

This study conducted a comparative analysis between two classes of student business programs, 2015 and 2016 classes at Telkom University. Classes 2015 and 2016 have chosen specializations in their courses, namely choosing between topics of marketing, human resources, and entrepreneurship. We only use the entrepreneurial concentration of students as the object of research because they have got entrepreneurship specialization courses. The 2015 class receives more entrepreneurship courses than the 2016 class. We conduct a comparative analysis because we want to understand the difference between two classes with different knowledge about entrepreneurship courses by measuring their Individual Entrepreneurship Orientation (IEO) and self-esteem towards their entrepreneurial intentions.

Entrepreneurial Orientation or EO used begins with Miller (1983), Covin and Slevin (1989), augmented by Lumpkin and Dess (1996) and by George and Marino (2011) who use it a different focus from entrepreneurship but towards management and marketing for a healthcare industry. The five components of EO are innovativeness, pro-activeness, risk-taking, autonomy and competitive aggressiveness. Innovativeness is emphasizing about the product or service they provided for their market. Some theories stated that innovativeness related to entrepreneurship where an entrepreneur creates a variety of new combinations of resources to start his business serving chosen markets. Proactiveness is pointing the entrepreneurial actions to manage future opportunities in terms of technologies, products, markets and customer demands. 
Some theories state that innovation related to entrepreneurship where an entrepreneur creates various combinations of new resources to start his business serving the chosen market. This characteristic is at the center of early economic thinking in this field: they think of entrepreneurs as someone who identifies opportunities in the market and pursues them (Lumpkin and Dess, 1996). Risk taking is an important characteristic associated with entrepreneurship. This refers to the risk of individuals about making business decisions for themselves. Autonomy is an independent act of a team or individual to make their vision or business idea come true and complete without being constrained by other obstacles. The last is to show aggressiveness, about the way companies compete in their industries and that distinguish between companies that move away from direct competition or take on markets of their competitors.

This defines self-esteem as "a positive or negative judgment as the whole person on oneself" (Ferris, Lian, Brown, Pang, Keeping, 2010, p.566). Research has shown that high self-esteem provides a buffer against a variety of factors that can inhibit motivation or performance in the workplace of individuals - individuals with high self-confidence are more motivated to perform tasks in ways consistent with themselves (Ferris et. Al, 2010) They have studied self-esteem between different genders to determine whether there are different demands or expectations that affect male and female self-esteem. Entrepreneurs have certain personality types including risk taking, responsibility, independence, and self-confidence (Roberts and Robinson, 2010). In their research shows that entrepreneurs may really appreciate the ability of their business. Robinson, Stimpson, Huefner and Hunt (1991) say about the scale of the Entrepreneurial Attitude Orientation (EAO) which discusses measuring various attitudes in the business such as (1) Achievement in business (the ability of individuals to start and grow), (2) innovation in business, (3) the perception of personal control over business results (the ability of individuals to control results), and (4) self-confidence or trust in business. That's why we want to investigate by comparing individual IEOs with self-esteem to check if there is a correlation. We have included an examination of self-esteem, including one's self-esteem in performance, appearance and social action in the IEO measurement instrument.

There is a reliable measurement created by Bolton and Lane (2012) that can validate an IEO of a student by asking questions, such as "I act", "Where risk involved" or "I prefer to try my unique way when learning new things rather than doing it like everyone else does" in the IEO survey. Many questions could conclude the risk-taking, innovativeness and pro-activeness levels for the student's EO. Fig. 1 showed we used the research framework in this comparative analysis research between business program students' class of 2015 and 2016 at Telkom University.

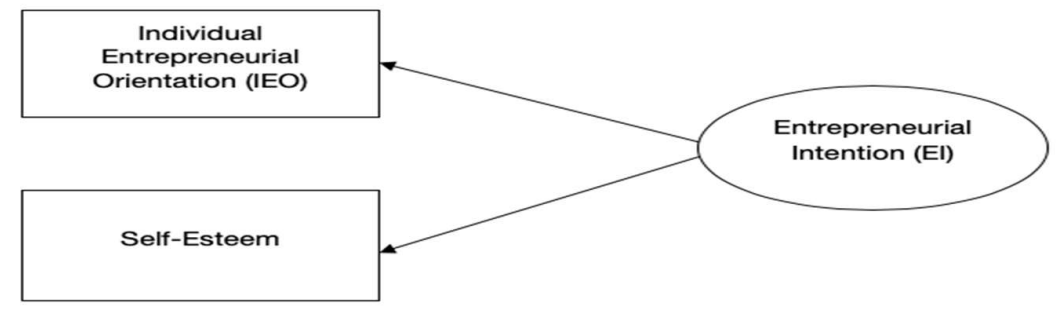

Figure 1. Research Framework

Hypotheses for Individual Entrepreneurship Orientation (IEO) are:

$\mathrm{H}_{10}$ : There is no significance difference of IEO between business program students' class of 2015 and 2016 toward an entrepreneurial intention.

$\mathrm{H}_{1 \mathrm{a}}$ : There is a significance difference of IEO between business program students' class of 2015 and 2016 toward an entrepreneurial intention.

Hypotheses for Self-Esteem are: 
$\mathrm{H}_{20}$ : There is no significance difference of Self-Esteem between business program students' class of 2015 and 2016 toward an entrepreneurial intention.

$\mathrm{H}_{2 \mathrm{a}}$ : There is a significance difference of Self-Esteem between business program students' class of 2015 and 2016 toward an entrepreneurial intention.

\section{Research Methodology}

This study uses the Bolton and Lane measurement scale (2012) and makes modifications to test the validity scale on the side of individual entrepreneurial orientation. This adds a question to the selfesteem dimension to the existing IEO measurement scale to test the self-esteem hypothesis. Then measure all indicators with a five-point Likert scale, is 1 to strongly disagree to 5 to strongly agree. We send surveys to students using direct letters. We asked students from two classes to provide answers to each statement mentioned in the IEO questionnaire and self-esteem. We chose purposive sampling to find out the total sample for this study. Arikunto (2012) says if your population is over 100 people means we can take $20-25 \%$ of the total population into a sample from the 2015 and 2016 classes of Telkom University. Validity test using Pearson Product-Moment correlation and reliability test using Cronbach alpha. Data analysis for comparing two classes is with the t-test because we want to compare the two averages and find out whether they differ from each other. Comparison of t-tests helps to determine whether 2015 and 2016 classes have many similarities or differences. The greater the $t$ score, the more differences between groups or classes. The smaller the $t$ score, the more similarities between groups.

Table 1. Items to Measure of IEO

\begin{tabular}{|l|l|}
\hline \multicolumn{2}{|l|}{ IEO Factors: } \\
\hline Innovativeness & $\begin{array}{l}\text { I often like to try new and unusual activities that are not typical but not } \\
\text { necessarily risky. } \\
\text { I tend to do things the same and not try different, unproven approaches. } \\
\text { I prefer to try my own unique way when learning new things rather than doing it } \\
\text { as everyone else does. } \\
\text { I favor experimentation and original approaches to problem-solving rather than } \\
\text { using methods others generally use for solving problems. }\end{array}$ \\
\hline Proactiveness & $\begin{array}{l}\text { I usually act in anticipation of future problems, needs or changes. I tend to plan } \\
\text { on projects. } \\
\text { I prefer to 'step up' and get things going on projects rather than sit and wait for } \\
\text { someone else to do it. }\end{array}$ \\
\hline Risk-Taking & $\begin{array}{l}\text { I like to take bold action by venturing into the unknown. } \\
\text { I am willing to invest a lot of time and/or money on something that } \\
\text { might yield a high return. } \\
\text { I tend to act 'boldly' in situations where risk is involved. }\end{array}$ \\
\hline
\end{tabular}

Source: Laura Vogelsang, 2015 
Table 2. Items to Measure of Self-Esteem

\begin{tabular}{|l|l|}
\hline Self-Esteem Factors: \\
\hline Performance & $\begin{array}{l}\text { I feel confident about my abilities } \\
\text { I feel frustrated or rattled about my performance. } \\
\text { I feel that I am having trouble understanding things that I read. I feel as smart as } \\
\text { others. } \\
\text { I feel confident that I understand things. } \\
\text { I feel that I have less scholastic ability right now than others. } \\
\text { I feel like I'm not doing well. }\end{array}$ \\
\hline Appearance & $\begin{array}{l}\text { I feel satisfied with the way my body looks right now. I feel that others respect } \\
\text { and admire me. } \\
\text { I am dissatisfied with my weight. } \\
\text { I feel good about myself. } \\
\text { I am pleased with my appearance right now. I feel unattractive. }\end{array}$ \\
\hline Social & $\begin{array}{l}\text { I am worried about whether I am regarded as a success or failure. I feel self- } \\
\text { conscious. } \\
\text { I feel displeased with myself. } \\
\text { I am worried about what other people think of me. I feel inferior to others at this } \\
\text { moment. } \\
\text { I feel concerned about the impression I am making. I am worried about looking } \\
\text { foolish. }\end{array}$ \\
\hline
\end{tabular}

Source: Laura Vogelsang, 2015

\section{Result and Analysis}

We review all samples for its validity and completeness for total 196 students of class 2015 and 2016 business program at Telkom University. We see the respondent's characteristic based on their class in table 3 that showed 196 students choose entrepreneurial specialization courses from total 750 students of two classes.

Table 3. Respondent profile

\begin{tabular}{|c|c|c|}
\hline Business Program Students & Frequency & Percentage \\
\hline Class of 2015 & 83 & 42.3 \\
\hline Class of 2016 & 113 & 57.5 \\
\hline Total & 196 & $100 \%$ \\
\hline
\end{tabular}

Source: processed data on 2018

We conducted a descriptive analysis for all statements on the questionnaire as a result between two classes (table 4). Class 2016 shows better scores for each IEO and self-esteem than for class 2015. We calculated composite scores for IEO which comprised three construct characteristics. 
Table 4. Recapitulation of Individual Entrepreneurship Orientation (IEO) and self-esteem of class 2015 and 2016 Business Program of Telkom University

\begin{tabular}{lcclccc}
\hline $\begin{array}{l}\text { Business Program } \\
\text { Students of Telkom } \\
\text { University }\end{array}$ & In \# & In $\%$ & Result & In \# & In \% & Result \\
\cline { 2 - 7 } $\begin{array}{l}\text { Individual Entrepreneurial Orientation (IEO) } \\
\text { Innovativeness }\end{array}$ & 999 & $63 \%$ & Adequate & 1692 & $75 \%$ & Good \\
Proactiveness & 718 & $58 \%$ & Adequate & 1231 & $73 \%$ & Good \\
Risk-Taking & 778 & $63 \%$ & Good & 1257 & $74 \%$ & Good \\
\hline Self-Esteem & & & & & & \\
Performance & 1697 & $58 \%$ & Adequate & 2541 & $62 \%$ & Adequate \\
Appearance & 1448 & $58 \%$ & Adequate & 2097 & $62 \%$ & Adequate \\
Social & 1549 & $53 \%$ & Adequate & 2178 & $55 \%$ & Adequate \\
\hline
\end{tabular}

Source: processed data on 2018

Based on the research conducted by distributing questionnaires to 196 respondents with 30 questions. The SPSS 20 tool processes data using a t-test analysis showing differences in results between 2015 and 2016 classes in almost all individual entrepreneurial orientation variables and self-confidence. From this information, the difference in the average perception of individual entrepreneurial orientation concludes that the 2016 class is 36.9 is better or higher than the 2015 class which is 30.1 . For details of the comparison of the averages in the dimensions of individual entrepreneurial orientation are as follows (as seen in table 5):

Table 5. Class of 2015 and 2016 vs. IEO and Self-Esteem

\begin{tabular}{|c|c|c|}
\hline MEANS & Class of 2015 & Class of 2016 \\
\hline \multicolumn{3}{|c|}{ Individual Entrepreneurial Orientation (IEO) } \\
\hline Innovativeness & 2.0 & 14.9 \\
\hline Proactiveness & 8.6 & 10.9 \\
\hline Risk-Taking & 9.7 & 11.1 \\
\hline \multicolumn{3}{|l|}{ Self-Esteem } \\
\hline Performance & 20.4 & 21.7 \\
\hline Appearance & 17.4 & 18.5 \\
\hline Social & 18.6 & 19.3 \\
\hline
\end{tabular}

Source: processed data on 2018

From table 5, we can see from the dimensions of innovation that the average got by the 2015 class is 2.0 smaller than the average in the 2016 class of 14.9. The proactive dimension shows that the average got by the 2015 class is 8.6 smaller than the average in the 2016 class of 10.9. In the Risk dimension, the average got by the 2015 class is 9.7 smaller than the average in the 2016 class of 11.1. Perception of self-confidence, the results of the 2015 class average are 56.5 which are smaller than 2016 registration, which is 59.5. For details of the mean comparisons in the dimensions of individual entrepreneurial orientation are: Performance Dimensions show the average got by the 2015 class is equal to 20.4 smaller than the average in the 2016 class of 21.7. The Appearance Dimension tells the average got by the 2015 class is 17.4 smaller than the average in the 2016 class of 18.5 . The Social Dimension shows the average got by the class in 2015 was 18.6 smaller than the average in the 2016 
class of 19.3. Based on the above details, we concluded that all variables in this study are individual entrepreneurial orientation variables with risk, innovation, and proactive dimensions, and variables of self-confidence with performance, appearance, and social dimensions in class 2016 have higher scores than class 2015. Class 2016 is better in the IEO and their Self-Esteem to start a business compared to the class of 2015 , even though they have not received as many specifications of entrepreneurial courses as the 2015 class.

Assessment of IEO scores. From table 6, the results of the comparison test calculations using the ttest show that the perceptions of individual entrepreneurial orientation between the 2015 and 2016 classes have a significant difference because the p-value or significance is below 0.05 (Hypothesis 1 is accepted). Individual perceptions of entrepreneurial orientation for 2016 are higher when compared to the class 2015 perceptions of individual entrepreneurial orientation.

The average difference of the two forces is -6.8 , which means the minus sign shows a higher score, namely the 2016 class entrepreneurial orientation perception score is better or higher than the 2015 class. We consider this means the class 2016 is to be bolder in taking risky actions, show more courage in risky situations involved, and are more willing to invest money when they want to start and own a business.

Assessment of Self-Esteem scores. From table 6, the results of the comparison test calculations using the t-test show that the confidence perception of self-esteem between the 2015 and 2016 classes has a significant difference because the p-value or significance is below 0.05 (Hypothesis 2 is accepted). The perception of self-confidence in the 2016 class is higher when compared to the 2015 self-esteem perception.

The average difference between the two classes is -3 , so the minus sign shows the strength of the class of 2016 is having a perception of self-esteem that is better or higher compared to the class of 2015. This means we consider the class of 2016 better or higher than the 2015 .

Table 6. Class of 2015 and 2016 vs. IEO and Self-Esteem used T-Test

\begin{tabular}{lcc}
\hline & Class of 2015 & Class of 2016 \\
\hline Individual Entrepreneurial & Orientation (IEO) & \\
Number & 83 & 113 \\
Minimum & 12 & 18 \\
Maximum & 41 & 50 \\
Means & 30.1 & 36.9 \\
Standard Deviation & 5.6 & 7.7 \\
P-Value & 0.000 & 0.000 \\
Significance & Accept Ho & Accept Ho \\
Self-Esteem & & \\
Number & 83 & 113 \\
Minimum & 50 & 50 \\
Maximum & 66 & 72 \\
Means & 56.5 & 59.5 \\
Standard Deviation & 3.8 & 4.9 \\
P-Value & 0.000 & 0.000 \\
Significance & Accept $\mathrm{H}_{1}$ & Accept H \\
\hline Source: processed data on 2018 & \\
& &
\end{tabular}




\section{Conclusion}

This research uses Bolton and Lane (2012) tools called Individual Entrepreneurial Orientation (IEO) to test through a survey of 196 business program students at Telkom University. We want to examine the correlation between students' IEOs and their self-esteem towards their entrepreneurial intentions. We want to measure it because we consider this information to be important to identify the success of individuals starting their own businesses as business owners or entrepreneurs with entrepreneurial skills and knowledge given at universities.

\section{References}

Aslam, T. M., Awan, A. S., \& Khan, T. M. (2012). Entrepreneurial intentions among university students of Punjab, a province of Pakistan. International Journal of Humanities and Social Science, 2(14): 114-120.

Bolton, D.; Lane, M., (2012). Individual entrepreneurial orientation: development of a measurement instrument. Education + Training, Vol. 54 Iss: 2 pg. 219 - 233.

Ferris, D., Lian, H. , Brown, D. , Pang, F. , \& Keeping, L. (2010). Self-esteem and job performance: The moderating role of self-esteem contingencies. Personnel Psychology, Vol. 63 Iss: 3 pg. 561593.

Hatammimi, J.; Fauziyah, Y., (2013). Pemahaman terhadap Matakuliah Entrepreneurship dan Kaitannya dengan Keinginan Memulai Bisnis. Jurnal Entrepreneur dan Entrepreneurship Vol. 2 No. 1 Hal. 83-92

Lau, V.; Shaffer, M.; Au, K. (2007) Entrepreneurial Career Success from a Chinese Perspective: Conceptualization, Operationalization, and Validation. Journal of International Business Studies Vol. 38 pg 126-146.

Laura Vogelsang (2015), Individual Entrepreneurial Orientation: An Assessment of Students. The Faculty of Humboldt State University, California, US.

Lumpkin, G.; Dess, G. (1996). Clarifying the Entrepreneurial Orientation Construct and Linking it to Performance. Academy of Management Review Vol. 21 Iss: 1 pg. 135-172.

Roberts, L., \& Robinson, P. (2010). Home-based entrepreneurs, commercial entrepreneurs and whitecollar workers: A comparative study of attitudes toward self-esteem, personal control and business growth. Journal of Small Business and Entrepreneurship Vol. 23 Iss: 3 pg. 333-353.

Sisilia, K. (2017). Wirausaha Masa Depan: Analisis Kepribadian Kewirausahaan Mahasiswa Bisnis. Optimal, Jurnal Ekonomi dan Kewirausahaan No. 2 2017, hal. 104-119. 